\title{
Novatoriska iepakojuma ietekme uz piena pomādes konfekšu - šerbeta - kvalitāti uzglabāšanas laikā Influence of Innovative Packaging on the Quality of Milk Pomade Sweets - Sherbet - during Storage
}

\author{
Eva Ungure*, Sandra Muzniece-Brasava, Lija Dukalska \\ LLU Pārtikas tehnologijas katedra \\ Department of Food Technology, LLU
}

\begin{abstract}
The objective of the research was to evaluate the quality of milk pomade sweet - sherbet - packaged in different packaging materials, using various packaging technologies. Four packaging materials were employed: two biodegradable films (Ceramis ${ }^{\circledR}-\mathrm{PLA}$ coated with a barrier of pure silicon oxide [SiOx], and metallised NatureFlex 23NM), and two conventional films (metallised BOPET/PE, and Multibarrier $60 \mathrm{HFP}$ as a control). Samples of sherbet were packaged using several technologies: active packaging (with incorporated ironbased oxygen scavenging sachets), modified atmosphere packaging consisting of $100 \% \mathrm{CO}_{2}$, and surrounding air ambience (control). The physicochemical properties - moisture, hardness, and colour - were analysed before packaging and after $2,4,6,8,10,12,14$, and 16 storage weeks. The samples were stored at room temperature $-+21 \pm 1{ }^{\circ} \mathrm{C}$. At the beginning of the experiment, the quality of sherbet was excellent in terms of taste, smell, colour, moisture content, and hardness expressed by cutting force. During the storage, those properties changed and the quality of the product decreased. The research suggests this can be explained by the loss of moisture in some samples leading to hardening of the product, which in its turn directly influenced the colour stability expressed by total colour difference $\Delta \mathrm{E}^{*}$.
\end{abstract}

Key words: Quality, milk pomade sweets, packaging technologies, shelf life.

\section{Ievads}

Konditorejas ražošanas un tirdzniecības tīkli ir lıtoti plaši, sākot no mājražotājiem, mazajiem veikaliem un filiālēm un beidzot ar lielākiem uzṇēmumiem. Konditorejas rūpniecība piedāvā daudzveidīgu izstrādājumu sortimentu, izmantojot apmēram 200 dažādu izejvielu (Quinton \& Kennedy, 2002; Manley, 1998).

Neskatoties uz daudzu cukura konditorejas izstrādājumu vienkāršīibu, tiem bieži vien ir sarežğîita struktūra. Tās nodrošināšanai liela nozīme ir cukura fizikālajam stāvoklim un produkta mitruma saturam. Piemēram, ūdens saturs cietās konfektēs ir minimāls - aptuveni no $1.5 \%$ līdz 5\% (Reinheimer, Mussati, Scenna, \& Pérez, 2010). Šāds ūdens saturs nepieciešams, lai izgatavotu konfektes ar noteiktu realizācijas termiṇu (Reinheimer, Mussati, \& Scenna, 2010).

Cukura konditorejas izstrādājumi pēc definīcijas ir produkti, kas galvenokārt satur viena veida cukuru vai vairāku cukuru veidu kombinācijas: saharozi (parasti cukurniedru vai cukurbiešu cukurs), dekstrozi (glikoze), fruktozi (bieži minēta kā augl̦u cukurs) vai laktozi (piena cukurs) (Ergun, Lietha, \& Hartel, 2010; Labuza et al., 2004; Zumbé, Lee, \& Storey, 2001; Barbiroli \& Mazzaracchio, 1994). Cukura konditorejas izstrādājums - šerbets - pieder pie Austrumu saldumiem, kam galvenās sastāvdal̦as ir cukurs, glikozes sīrups un iebiezinātais piens. Visas šīs sastāvdaļas tiek vārītas, veidojot viendabīgu masu, kuru pēc tam saputo, lai iegūtu piena pomādes konfektes. Tikko gatavots šerbets ir mīksts un gards, bet pēc vairāku dienu uzglabāšanas gaisa vidē tas pamazām sacietē, zaudē vizuālo izskatu un garšu un kḷūst nepievilcīgs tirdzniecībai. Šì problēma ierobežo realizācijas laiku, tāpēc šerbetu iespējams pārdot tikai vietējā tirgū (Vaclavik \& Christian, 2008; Ben-Yoseph \& Härtel, 2006; Labuza et al., 2004).

Šobrīd konditorejas izstrādājumus tirdzniecībā realizē divos veidos - kā sveramus produktus, kurus izsver tirdzniecības vietās, un kā produkciju,

\footnotetext{
* Corresponding author's email: 
kas jau ražotājuzņēmumos safasēta noteikta izmēra iepakojumos un ar noteiktu svaru, izmantojot vienslān,a iepakojuma materiālus bez barjerīpašībām; līdz ar to šādā iepakojumā netiek nodrošināta produkta kvalitāte.

Palielinoties globālā tirgus apjomam un pieprasījumam, konditorejas ražotājiem savu produkciju nākas eksportēt arvien lielākā attālumā, kas savukārt aizn̦em vairāk laika. Uzglabājot pārtikas produktus, to kvalitāti būtiski ietekmē vide, kura apñem produktu. Daudzos produktos kritisks process ir oksidācija. Skābekḷa klātbūtnē pārtikas produktos notiek neatgriezeniskas izmaiñas, piemēram, tauki un ellıas oksidējas, produkti kḷūst rūgti, tajos samazinās vitamīnu daudzums, mainās krāsa, zūd aromātvielas un palielinās mikroorganismu kopskaits. Savukārt pārāk liels mitruma saturs izraisa hidrolītiski piesātināto tauku sasmakšanu (piemēram, riekstos), kā arī negatīvi ietekmē pārtikas produktu struktūru un garšu. Pārtikas produktu kvalitātes pazemināšanos skābekḷa klātbūtnē veicina arī paaugstināta temperatūra, mitrums, ūdens aktivitāte un gaisma (Sucharzewska, Stochmal, \& Oleszek, 2003; Manley, 1998; Mexis, Badeka, Riganakos, \& Kontominas, 2010).

Lai produktus varētu uzglabāt un lietot ilgāku laika periodu un lai tie spētu apmierināt gan ražotāju, gan patērētāju vēlmes un prasības, jāpievērš uzmanība trīs faktoriem: paša produkta īpašībām; videi, kurā produkts atrodas izplatīšanas laikā; un iepakojuma materiāla īpašībām (Labuza et al., 2004; Raisi \& Aroujalian, 2007).

Daudzi zinātnieki mūsdienās pēta dažādus veidus, kā saglabāt konditorejas izstrādājumu kvalitāti un pagarināt to uzglabāšanas laiku (López-Carballo, Catalá, Gavara, \& Hernįndez-Muńoz, 2011; Ergun, Lietha, \& Hartel, 2010; Restuccia et al., 2010; Raisi \& Aroujalian, 2007; Labuza et al., 2004). Tādējādi novatoriskas iepakošanas metodes, piemēram, daži biodegradējamie materiāli ar atbilstošām īpašībām un aktīvais iepakojums, varētu aizsargāt produktus no atkārtota sekundārā, fizikālā, ķīmiskā un mikrobioloǵiskā piesārṇojuma, realizācijas laikā nodrošinot produktu kvalitāti tirdzniecības vietās un pagarinot realizācijas termiņu, kā arī samazinot izlietotā iepakojuma iespējamo kaitīgo ietekmi uz vidi un samazinot produktu zudumus (Arella, Buzarovska, Errico, Gentile, \& Grozdanov, 2009; Farris, Schaich, Liu, Piergiovanni, \& Yam, 2009).

Iepakojums ne tikai aizsargā pārtikas produktus no jebkāda fizikālā, ķīmiskā vai mikrobioloǵiskā piesārņojuma, bet arī apvieno sevī gan mākslu, gan zinātni vienlaicīgi, līdz ar to nodrošinot patērētājam atraktīvu produktu pasniegšanu (Mathlouthi, 1994). Iepakošana ir viens no efektīvākajiem un mūsdienās pieejamākajiem tirgus veicināšanas paņēmieniem. Atbilstošam un kvalitatīvam iepakojumam ir liela nozīme gan produkta kvalitātes saglabāšanā, gan arī pievienotās vērtības radīšanā precei.

Lai nodrošinātu nemainīgu produkta kvalitāti tā uzglabāšanas laikā, jāizvēlas piemērotākā iepakošanas tehnologija un atbilstošākais iepakojuma materiāls. Starp iepakojuma materiālu attīstības tendencēm un pārtikas produktu realizācijas termiṇu pagarināšanu pastāv cieša mijiedarbība. Līdz šim pārtikas iepakojumam galvenokārt lietoja no fosilām izejvielām ražotus polimērus, taču situācija ar katru brīdi mainās. Biopolimēru ražotāji paredz ražošanas apjomu palielināšanos un līdz ar to arī augsto no dabā atjaunojamām izejvielām ražoto biopolimēru izmaksu pakāpenisku samazināšanos (Farris, Schaich, Liu, Piergiovanni, \& Yam, 2009; Avella et al., 2005; Tharanathan, 2003).

Pētījumi par biologiiski noārdāmo materiālu lietošanu pārtikas iepakojumam tiek veikti nepārtraukti. Biopolimēri salīdzinājumā ar tradicionāli lietotajiem polimēriem, ko iegūst no naftas produktiem, ir dabai draudzīgi. Tos izgatavo no dabā regulāri atjaunojamām izejvielām, to ražošanas procesā tiek patērēts salīdzinoši mazāk enerǵijas, un tie augsnē esošo mikroorganismu, mitruma, saules gaismas un atbilstošas temperatūras ietekmē sadalās par $\mathrm{CO}_{2}$ un $\mathrm{H}_{2} \mathrm{O}$ un iekḷaujas materiālu aprites dabiskajā slēgtajā ciklā (Funabashi, Ninomiya, \& Kukioka, 2009; Silagyi, Kimn, Lo, \& Wei, 2009; Vorman \& Tighzert, 2009; Siracusa, Rocculi, Romani, \& Rosa, 2008; Narayan, 2001).

Interese par biologiski noārdāmo iepakojuma materiālu izmantošanu pēdējo gadu laikā palielinās (Mitrus, Wojtowicz, \& Moscicki, 2009; Talja, Helen, Roos, \& Jouppila, 2008; Veiga-Santos, Suzuki, Nery, Cereda, \& Scamparini, 2008; Avella et al., 2005; Tharanathan, 2003).

Neskatoties uz to, ka biopolimēru ražotāji piedāvā vairākus speciāli konditorejas izstrādājumu iepakojumam paredzētus biodegradējamos materiālus, zinātniskajā literatūrā ir maz informācijas par biolog̣iski noārdāmo materiālu izmantošanu cukura konditorejas izstrādājumu iepakošanai.

Firma Innovia Films 2006. gadā sāka tirgot metalizētu biodegradējamu plēvi NatureFlex NM, kas iegūta no koksnes celulozes. Tā biologiski sadalās, ir sertificēta pēc EN 13432 protokola, 
atbilst standartam ASTM D6400, un tai ir lioti augsta mitruma barjera (Innovia Films, 2006). Plēve skaisti mirdz un atstaro gaismu, labi izskatās veikalu plauktos un ir piemērota dāvanu iesaiņošanai, tādēl to iesaka konfekšu iepakošanai. Turklāt plēvei piemīt antistatiskas īpašības, tā ir piemērota lietošanai jebkurā iepakošanas iekārtā un, pats galvenais, tā novērš konfekšu pielipšanu pie iepakojuma (Mitrus, Wojtowicz, \& Moscicki, 2009). Vieni no galvenajiem saldumu ražotājiem pasaulē Cadbury (NatureFlex ..., 2010) un Lielbritānijas konfekšu ražotāji Thorntons (Innovia Films, 2010), kā arī Kanādas uzṇēmēji (Innovia Films, 2009) šo plēvi izvēelējušies savas produkcijas prezentēšanai - galvenokārt lai veicinātu Zal̆o programmu. Plēvei ir labas gāzu un mitruma barjerīpašības, to var gan labi sakausēt, gan arī savīt, kas nepieciešams konfekšu iet̄̄šanai. NatureFlex $N M$ plēvē metāla jonu saturs nepārsniedz 0.02\%, kas nedaudz palēnina plēves sadalīšanās procesu, taču tam arī netraucē.

Mūsdienās izgatavoti vairāki jaunākās paaudzes biomateriāli ar uzlabotām barjerīpašībām, piemēram, Ceramis ${ }^{\circledR}-P L A$ plēve. Tās barjerīpašības uzlabo silīcija oksīda $\left(\mathrm{SiO}_{2}\right)$ pārklājums, tā ir izgatavota no dabā regulāri atjaunojamām izejvielām ar enerğiju taupošu tehnologiju, ir sertificēta DIN CERTCO un ir rūpnieciski kompostējama 47 dienu laikā. Šai plēvei paredz l̦oti plašu lietošanas spektru pārtikas iepakošanai, īpaši aizsarggāzu vidē (Glaw, 2007; Europe's packaging ..., 2007; Alkan packaging, 2006). Kompānija VC999 ir pirmais ražotājs, kas lietojis šādu ar $\mathrm{SiO}_{2}$ pārklātu PLA plēvi pārtikas produktu iepakošanai aizsarggāzu vidē un sasniedzis līdzīgu ietekmi uz derīguma termiṇu PP iepakojumā ar EVOH barjerslāni (Meyer, 2007).

Neskatoties uz aktīvu pētniecisko darbu par biologíski noārdāmo materiālu piemērošanu konditorejas izstrādājumu iepakošanai, trūkst zinātniski pamatotu datu, kas saistīti ar produktu kvalitātes izmaiņām iepriekšminētajos iepakojumos, kā arī vērojama arvien pieaugoša interese par jaunu iepakojuma tehnoloǵiju izstrādi, attīstību un ieviešanu ražošanā.

Aktīvais iepakojums ir novatoriska iepakojuma tehnologija, ar kuras palīdzību iespējams pagarināt pārtikas produktu derīguma termiņu (Ahvenainen, 2003). Tas ražotāju un patēēetāju interesi arvien plašāk piesaista pārtikas produktu kvalitātei un drošībai, galvenokārt iepakojumā uzglabāšanas laikā (Scussel et al., 2010; Rooney, 1995; 2005a; Vermeiren, Devleighere, van Beest, de Kruijf, \& Debevere, 1999; Taub \& Singh, 1998). Aktīvais iepakojums var sniegt risinājumu, lietojot materiālus vai ķīmiskus savienojumus, kuri absorbē vai atbrīvo īpašus maisījumus gāzes fāzē. Savienojumi, kurus var absorbēt, ir oglekḷa dioksīds, skābeklis, ūdens tvaiks, etilēns vai gaistošās vielas, kuras ietekmē pārtikas produktu garšu un aromātu (Thippeswamy, Venkateshaiah, \& Patil, 2011; Lagaron \& LópezRubio, 2010; Mexis, Badeka, Riganakos, \& Kontominas, 2010; Lopez-Rubio et al., 2004).

Skābekḷa aizvadīšanu no iepakojuma iespējams kombinēt ar gaisa vidi, aizsarggāzu vidi vai vakuumiepakojumu. To parasti izmanto savstarpēji papildinošā veidā (Lagaron \& López-Rubio, 2010; Scussel et al., 2010; Rooney, 2005b).

Saldumu tirgū īpaši piemērotas ir divas absorbentu tehnologijas - skābekḷa un mitruma satura regulētāji. Skābekḷa absorbenti iepakojumā samazina skābekḷa saturu $(>0.01 \%)$, tādējādi pasargājot produktus no sasmakšanas un tauku oksidēšanās un kavējot mikroorganismu augšanu. Savukārt mitruma aizvācēju tehnoloǵija samazina mitruma saturu iepakojuma vidē līdz tādam līmenim, kas nomāc hidrolīzi taukos un eḷıās, tādējādi izmainot pārtikas produktu organoleptiskās īpašības. Minētie absorbenti (skābekḷa un mitruma aizvācēji) l̦auj saldumu ražotājiem saglabāt produkcijas aromātu un krāsu, uzturēt atbilstošu tās struktūru un līdz ar to pagarināt produktu vispārējo derīguma termiņu.

Produktu garšas izjūtu, struktūru un organoleptisko kvalitāti nelabvēlīgi ietekmē mitruma zudums saldumos. Mitruma regulēšanu iepakojumā iespējams apvienot ar skābekḷa absorbentiem, vienlaicīgi arī saglabājot optimālu relatīvo mitrumu iepakojumā. Šāda pieeja konditoriem l̦auj optimizēt vai samazināt emulgatoru, virsmaktīvo vielu un citu piedevu izmantošanu (Rooney, 1995; Scussel et al., 2010; Vermeiren, Devleighere, van Beest, de Kruijf, \& Debevere, 1999).

Visbiežāk izmantotās skābekḷa absorbētāju tehnologijas pamatojas uz dzelzs (Fe) reakciju ar skābekli, kā rezultātā veidojas dzelzs oksīds. Zinātnieki Jensen, Sorensen, Brockhoff un Bertelsen (2003) valriekstu realizācijas laika pagarināšanai sekmīgi izmantojuši skābekḷa absorbētājus. Savukārt zinātnieku grupai Pastorelli (Pastorelli et al., 2007) vadībā, veicot pētījumus par smalcinātu lazdu riekstu uzglabāšanu aktīvajā iepakojumā, izdevies pagarināt riekstu realizācijas laiku. Pētnieki akcentē, ka paralēli aktīvajam elementam skābekḷa daudzumu iepakojumā būtiski var kontrolēt arī ar tādiem iepakojuma materiāliem, kuriem ir augstas gāzu barjerīpašības (t.i., zema skābekḷa caurlaidība) 
(Mexis, Badeka, Riganakos, \& Kontominas, 2010; Rooney, 2005b).

Biopolimēru materiālu un aktīvā iepakojuma tehnoloǵiju izmantošana konditorejas izstrādājumu realizācijas termiņa pagarināšanai Latvijā nav pētīta, kā arī literatūras avotos nav atrodama informācija par to ietekmi uz cukura konditorejas izstrādājumu kvalitāti uzglabāšanas laikā.

Pētījuma mērķis bija novērtēt piena pomādes konfekšu - šerbeta - kvalitātes izmaiņas, tās ilgstoši uzglabājot dažādos jauna veida iepakojuma materiālos (konvencionālos, ar augstām barjerīpašībām un no dabīgām izejvielām ražotos bioloǵiski sadalāmos), kā arī izmantojot progresīvās iepakojuma tehnologijas - aktīvo iepakojumu ar skābekḷa absorbentiem un aizsarggāzes.

\section{Materiāli un metodes}

Eksperimenti veikti Latvijas Lauksaimniecības universitātes Pārtikas tehnoloǵijas katedras laboratorijās. Pētījuma objekts: neglazētas piena pomādes konfektes - zemesriekstu šerbets. To pagatavošanai izmantoja šādas izejvielas: cukuru, grauzdētus zemesriekstus, iebiezinātu pienu ar cukuru, glikozes sīrupu, sāli, vafeles. Šerbeta viena gabala izmēri vidēji bija $40 \times 40 \times 8 \mathrm{~mm}$, un masa $30 \pm 1 \mathrm{~g}$.

Paraugu sagatavošana un uzglabāšana. Šerbetu iepakoja maisiņos, pa diviem gabaliniem katrā; maisiña izmēri - 80×120 mm; kopējā produkta masa vienā iepakojumā $-60 \pm 2$ g. Iepakojuma maisiņi bija izgatavoti no dažādiem polimēra materiāliem ar atšķirīgām barjerīpašībām un biezumu: no metalizētas konvencionālās $B O P E T / P E$ plēves un no divu veidu biodegradējamām plēvēm (Ceramis ${ }^{\circledR}$ PLA plēve [VC999 BioPack PLA], kas pārklāta ar $\mathrm{SiO}_{2}$ barjerslāni, un metalizēta NatureFlex 23NM plēve, kas izgatavota uz celulozes bāzes). Par kontroles iepakojumu tika izmantota laminēta Multibarrier 60 HFP plēve ar augstām barjerīpašībām. Lietoto materiālu raksturojums dots 1 . tabulā.

Paraugus iepakoja gaisa vidē, aizsarggāzu vidē $\left(100 \% \quad \mathrm{CO}_{2}\right)$ un aktīvajā iepakojumā, kurā bija ievietotas Mitsubishi Gas Chemical Europe Ageless ${ }^{\circledR}$ uz dzelzs (Fe) bāzes gatavotas skābekḷa aizvācēju paketes ar $100 \mathrm{~cm}^{3}$ absorbcijas spēju (1. att.). Lai panāktu efektīvāku skābekḷa aizvākšanu, skābekḷa absorbentus iepakojumos kombinēja ar aizsarggāzu vidi $\left(100 \% \mathrm{CO}_{2}\right)$.

Paraugus uzglabāja istabas temperatūrā

Eksperimentos lietoto materiālu raksturojums

1. tabula / Table 1

\section{Characteristics of materials used in the experiments}

\begin{tabular}{|c|c|c|c|}
\hline $\begin{array}{l}\text { Parauga Nr. / } \\
\text { Sample No. }\end{array}$ & $\begin{array}{l}\text { Materiāla nosaukums / } \\
\text { Packaging material }\end{array}$ & $\begin{array}{l}\text { Raksturojums un sastāvs / } \\
\text { Characteristics and composition }\end{array}$ & $\begin{array}{c}\text { Biezums / } \\
\text { Thickness, } \\
\delta, \mu \mathrm{m}\end{array}$ \\
\hline 1. & $\begin{array}{c}\text { Multibarrier } 60 \mathrm{HFP} \\
\text { plēve, kontrole / } \\
\text { pouch, control }\end{array}$ & $\begin{array}{c}\text { Lamināts, } \\
\text { APA/TIE/PA/EVOH/PA/TIE/PE/PE, } \\
\text { caurspīīīgs / } \\
\text { Laminate, } \\
\text { APA/TIE/PA/EVOH/PA/TIE/PE/PE, } \\
\text { transparent }\end{array}$ & $60 \pm 2$ \\
\hline 2. & $\begin{array}{l}\text { Ceramis }{ }^{\circledR}-P L A \\
\text { plēve / pouch }\end{array}$ & $\begin{array}{c}\text { PLA pārklāts ar } \mathrm{SiO}_{2}- \\
\text { ar augstām barjerīpašībām / } \\
\text { PLA coated with } \mathrm{SiOx}- \\
\text { with high barrier properties }\end{array}$ & $60 \pm 2$ \\
\hline 3. & $\begin{array}{l}\text { Metalizēta NatureFlex } \\
\text { 23NM plēve / } \\
\text { Metallised NatureFlex } \\
\text { 23NM pouch } \\
\end{array}$ & $\begin{array}{c}\text { Metalizēta virsma/starpkārta/caurspīdīga } \\
\text { celulozes plēve } \\
\text { Metallised surface/coating/transparent } \\
\text { celulose film }\end{array}$ & $23 \pm 2$ \\
\hline 4. & $\begin{array}{l}\text { Metalizēta BOPET/PE } \\
\text { plēve / } \\
\text { Metallised BOPET/PE } \\
\text { pouch }\end{array}$ & $\begin{array}{l}\text { BOPET/ALU/PE } \\
\text { lamināts / laminate }\end{array}$ & $65 \pm 2$ \\
\hline
\end{tabular}




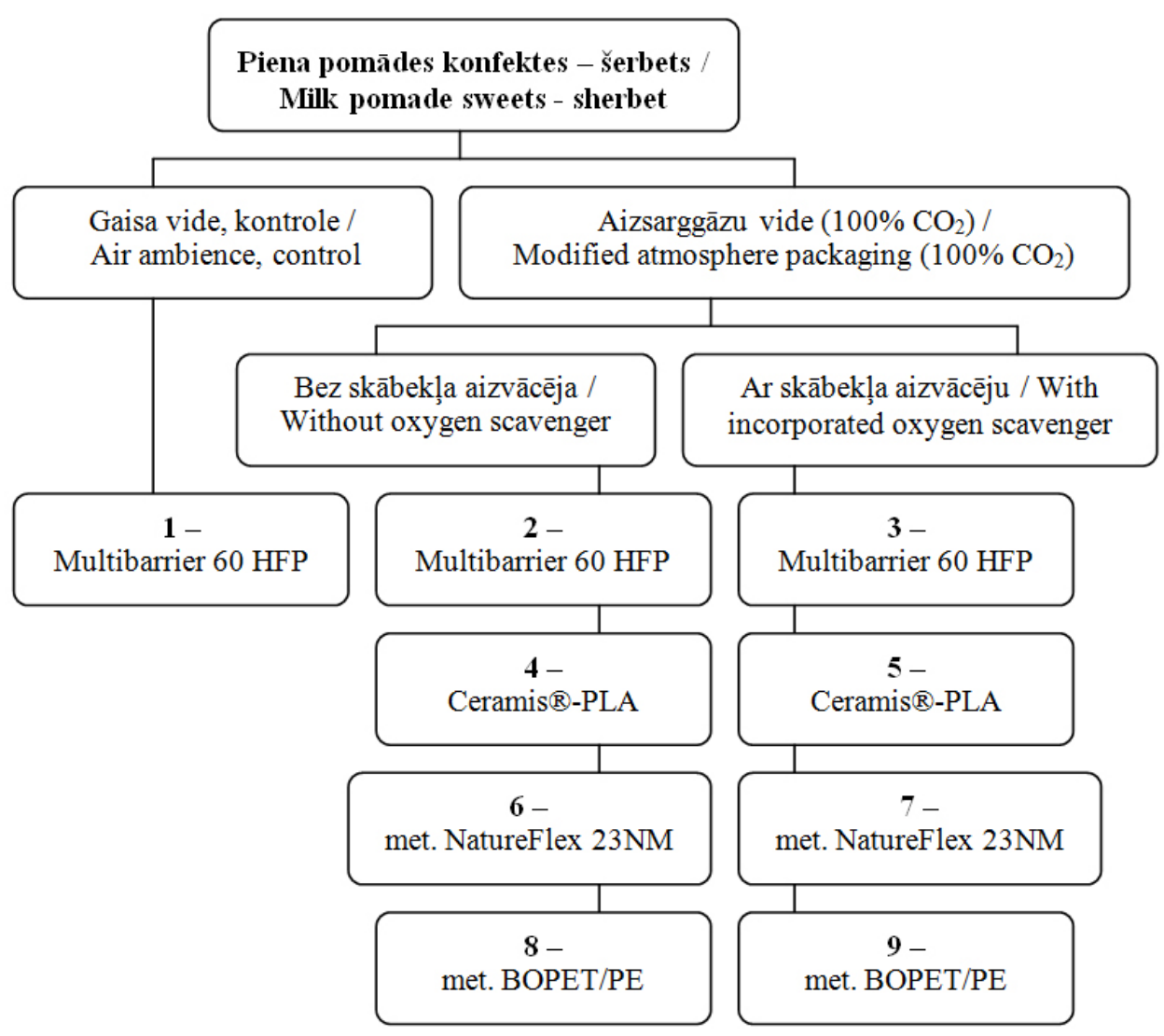

1. att. Veikto eksperimentu struktūra.

Fig. 1. Structure of the performed experiments.

$\left(+21.0 \pm 1.0{ }^{\circ} \mathrm{C}\right)$ un analizēja pirms iepakošanas (0. dienā) un pēc 2, 4, 6, 8, 10, 12, 14 un 16 uzglabāšanas nedēḷām.

\section{Produktu fizikāli k̦īmisko rādītāju noteikšanas metodes \\ Mitruma satura noteikšana. Mitruma saturu} piena pomādes konfektēm noteica ar mitruma svariem XM 120 Precisa, karsējot produktu paraugus $110^{\circ} \mathrm{C}$ temperatūrā līdz konstantai masai; rezultāta mērījumu nolasīja tad, kad trīs mērījumi ik pēc 20 sekundēm bija nemainīgi. Mitruma svaros ievietotā parauga

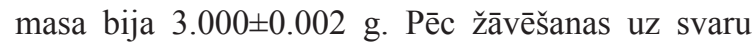
displeja nolasīja produkta mitrumu \%, kaltēšanu veicot trīs atkārtojumos.

Cietības noteikšana. Piena pomādes konfekšu cietību noteica ar struktūras analizatoru TA.XTplus, izmantojot speciāli paredzētu mērīšanas uzgali HDP/ BSK ar nazi. Mērīšanas laikā paraugu novietoja uz struktūras analizatora galdiña un mērīja griešanas spēku (N), ja naža pārvietošanās ātrums bija $10 \mathrm{~mm} \mathrm{~s}^{-1}$. Šādā ātrumā, asmenim iespiežoties produkta paraugā 17 mm dziļumā, noteica piena pomādes konfektes cietības maksimālo griešanas spēku. Šerbeta cietību katram paraugam noteica 10 atkārtojumos.

Krāsas L*a*b* mērījumi. Lai raksturotu šerbeta kvalitāti uzglabāšanas laikā, ar krāsas analizatoru ColorTec-PCM CIE pētītajiem paraugiem $\mathrm{L}^{*} \mathrm{a} * \mathrm{~b}^{*}$ krāsu sistēmā noteica krāsas komponentes. Katram iepakojumam atkārtoti veica 10 mērījumus 10 dažādos parauga punktos, lai aprēķinātu vidējo vērtību un standartnovirzi un iegūtu pēc iespējas precīzāku rezultātu. Datu apstrāde tika veikta ColorSoft $Q C W$ datu programmā.

Produkta krāsas komponenšu kopējās izmaiņas uzglabāšanas laikā raksturo to diferenču kvadrātu summa - kopējā diference $\Delta \mathrm{E}^{*}$, ko iegūst, izmantojot L*a*b* vērtību (1) (MacDougall, 2002):

$$
\Delta E^{*}=\sqrt{\left(L^{*}-L_{0} *\right)^{2}+\left(a^{*}-a_{0} *\right)^{2}+\left(b^{*}-b_{0}\right)^{2}},
$$

kur

$$
\begin{aligned}
\Delta E^{*}-\text { kopējā krāsas komponenšu diference, } \\
\text { kas raksturo produkta krāsas izmaiṇas } \\
16 \text { nedēḷu uzglabāšanas laikā; }
\end{aligned}
$$


$L^{*}$ - produkta krāsas intensitāti raksturojošā vērtība eksperimenta pēdējā dienā;

$L_{0} *$ - produkta krāsas intensitāti raksturojošā vērtība eksperimenta sākumā;

$a^{*}$ - produkta krāsas komponenti „zalı̆š-sarkans” raksturojošā vērtība eksperimenta pēdējā dienā;

$a_{0} *$ - produkta krāsas komponenti „zalı̌š-sarkans” raksturojošāà vērtība eksperimenta sākumā;

$b^{*}$ - produkta krāsas komponenti ,zilsdzeltens" raksturojošā vērtība eksperimenta pēdējā dienā;

$b_{0} *$ - produkta krāsas komponenti ,zilsdzeltens" raksturojošā vērtība eksperimenta sākumā.

\section{Sensorā novērtēšana}

Šerbeta sensoro īpašību novērtējums produkta uzglabāšanas laikā. Lai izvērtētu šerbeta cietības izmaiṇas uzglabāšanas laikā dažādos iepakojuma materiālos un dažādās uzglabāšanas vidēs, izmantojot 5 punktu hedonisko skalu (5 - viegli sakožams, mīksts; 1 - l̦oti ciets) (ISO 4121:2003), tika noteikta paraugu cietības pakāpe. Vērtěšanā piedalījās seši apmācīti vērtētāji, kuru vidējais vecums -37 gadi.

\section{Datu matemātiskā apstrāde}

Dati apstrādāti ar matemātiskās statistikas metodēm, izmantojot SPSS programmas SPSS 16 paketi, Microsoft Excel for Windows 7.0 programmas; $p$ vērtība raksturo iegūto datu būtiskuma zemāko līmeni $(p>0.05 \quad$ dati būtiski neatšksiras; $p<0.05$ - dati būtiski atšķiras). Iegūtajiem rezultātiem aprēķināta vidējā aritmētiskā vērtība un standartnovirze. Datu interpretācijai veikta vienfaktora un divfaktoru dispersijas analīze (ANOVA) ar atkārtojumiem (Bower, 2009).

\section{Rezultāti un diskusija}

Mitrums ir viens no galvenajiem rādītājiem, pēc kura patērētājs novērtē piena pomādes konfekšu kvalitāti. Uzglabāšanas laikā mitruma saturs konfektēs samazinās, kas izraisa to sacietēšanu. Iepakotā produkta mitruma zudumi lielā mērā atkarīgi no iepakojumam lietotā materiāla barjerīpašībām - ūdens tvaika caurlaidības.

Kontroles paraugam gaisa vidē iepakošanas materiālā Multibarrier $60 \operatorname{HFP}(2$. att. - 1) mitruma saturs 16 nedēḷu uzglabāšanas laikā samazinājās no

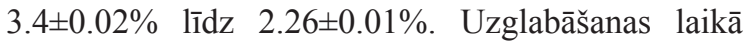
aizsarggāzu vidē $\left(100 \% \mathrm{CO}_{2}\right)$ un aktīvajā iepakojumā dažādos iepakojuma materiālos analizētajiem paraugiem lielākos mitruma satura zudumus novēroja biodegradējamos iepakojuma materiālos. Biodegradējamā Ceramis ${ }^{\circledR}-P L A$ (2. att. - 4 un 5) un metalizētā NatureFlex 23NM plēvē (2. att. - 6 un 7) mitruma saturs paraugos līdz uzglabāšanas laika beigām samazinājās līdz $1.21 \pm 0.01 \%$. Mazāki mitruma satura zudumi bija Multibarrier 60 HFP materiālā iepakotajam šerbetam, bet Multibarrier $60 \mathrm{HFP}\left(100 \% \mathrm{CO}_{2}\right)$ un Multibarrier $60 \operatorname{HFP}\left(\left[\begin{array}{lll}100 \% & \mathrm{CO}_{2}\end{array}\right]+\mathrm{O}_{2}\right.$ absorbents, $\left.100 \mathrm{~cm}^{3}\right)$ materiālā iepakotajiem šerbeta paraugiem mitruma saturs samazinājās attiecīgi līdz $2.59 \% \pm 0.01$ un $2.76 \pm 0.01 \%$.

Savstarpēji salīdzinot paraugus, konstatējām, ka metalizētā $B O P E T / P E$ (2. att. -8 un 9) materiālā iepakotie paraugi būtiski atšķīāās no visiem pārējiem pētītajiem paraugiem $(p<0.05)$. Mitruma satura izmaiñas tajos bija minimālas - sākotnējais mitruma saturs $(3.4 \pm 0.02 \%)$ šerbeta paraugos pēc 16 nedēḷu uzglabāšanas bija pazeminājies tikai attiecīgi līdz $3.2 \pm 0.01$ un $3.3 \pm 0.01 \%$. Būtisku ietekmi nebija devis arī iepakojumā ievietotais skābeklı absorbents.

Šerbeta mitruma satura izmaiņas skaidrojamas ar piena pomādes konfekšu uzglabāšanas laikā notiekošo mitruma migrāciju no produkta uz apkārtējo vidi: jo ilgāks uzglabāšanas laiks, jo lielāka apkārtējās vides ietekme. Izmantojot iepakojuma materiālus ar augstākām barjerīpašībām, mitruma samazināšanos produktā iespējams ierobežot. Savstarpēji salīdzinot paraugus, redzams, ka aizsarggāzu iepakojumā $\left(100 \% \quad \mathrm{CO}_{2}\right)$ ar un bez skābekḷa absorbentiem uzglabāšanas laikā līdz 16 nedēḷām paraugiem aktīvajā iepakojumā (2. att. - 3, 5, 7 un 9) bija mazāki mitruma zudumi.

Izmaiņas dažādi iepakoto piena pomādes konfekšu struktūrā, ko raksturo cietība N, uzglabāšanas laikā parādītas 3. attēlā. Kā rāda eksperimenta rezultāti, šerbeta struktūra uzglabāšanas laikā mainās un atbilstoši mitruma zudumam konfektes pakāpeniski sacietē. Pirmajās divās nedēḷās visiem paraugiem cietība palielinājās un sasniedza no $174.30 \pm 8.71$

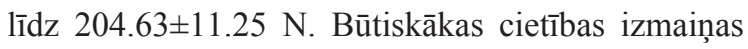
bija novērojamas, uzglabājot paraugus ilgāk par četrām nedēlāam. Pēc 16 nedēḷu uzglabāšanas paraugam Ceramis ${ }^{\circledR}-P L A$ plēvē $\left(100 \% \mathrm{CO}_{2}\right)$ cietība bija $680.59 \pm 19.62 \mathrm{~N}$, bet aktīvajā iepakojumā

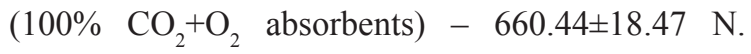
Starp Ceramis ${ }^{\circledR}-P L A$ plēvē iepakotajiem 


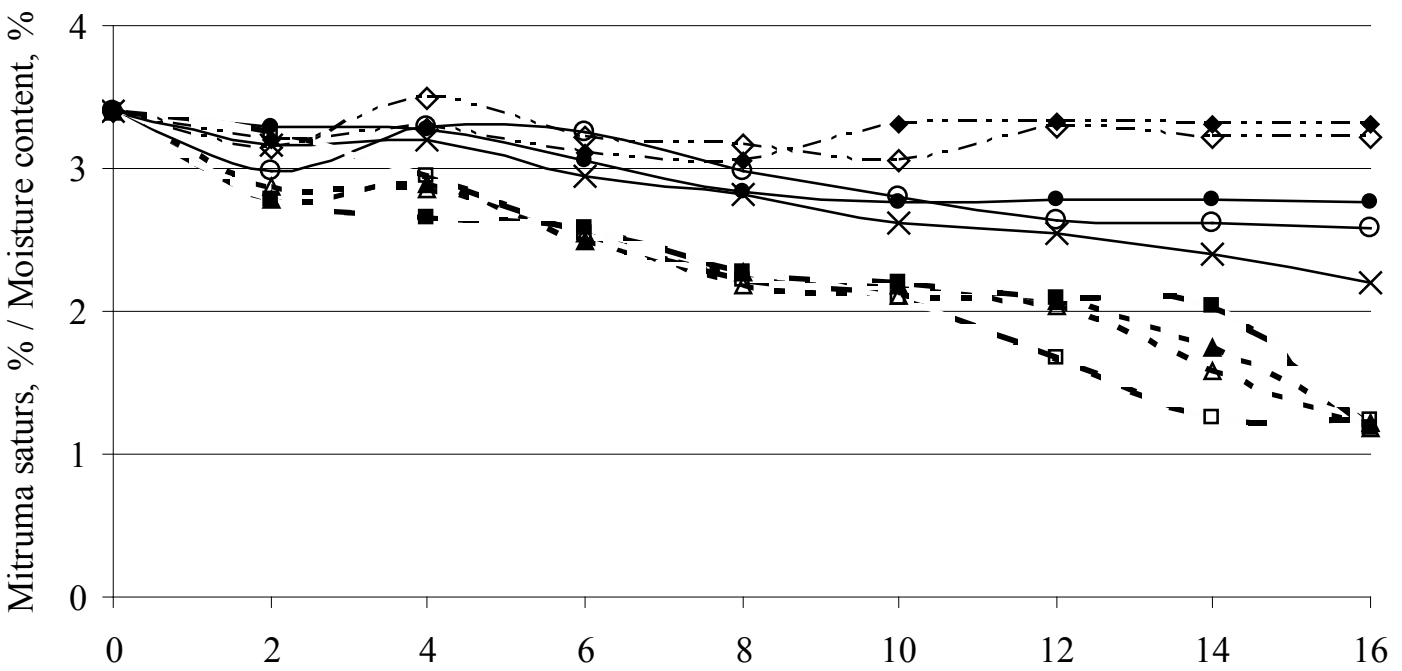

Uzglabāšanas laiks, nedēl̦as / Storage time, weeks

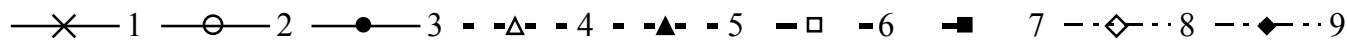

2. att. Šerbeta mitruma satura izmainsas uzglabāšanas laikā, \%:

1 - Multibarrier 60 HFP (kontrole gaisa vidē); 2 - Multibarrier $60 \mathrm{HFP}$ (vide - $100 \% \mathrm{CO}_{2}$ );

3 - Multibarrier $60 \mathrm{HFP}$ (vide - 100\% $\mathrm{CO}_{2}$ ) $+\mathrm{O}_{2}$ absorbents, $100 \mathrm{~cm}^{3} ; 4$ - Ceramis ${ }^{\circledR}$-PLA plēve

(vide $-100 \% \mathrm{CO}_{2}$ ); 5 - Ceramis ${ }^{\circledR}-P L A$ plēve (vide $\left.-100 \% \mathrm{CO}_{2}\right)+\mathrm{O}_{2}$ absorbents, $100 \mathrm{~cm}^{3}$;

6 - metalizēts NatureFlex 23NM (vide - 100\% $\left.\mathrm{CO}_{2}\right) ; 7$ - metalizēts NatureFlex 23NM

(vide $-100 \% \mathrm{CO}_{2}$ ) $+\mathrm{O}_{2}$ absorbents, $100 \mathrm{~cm}^{3} ; 8$ - metalizēts BOPET/PE (vide $-100 \% \mathrm{CO}_{2}$ ); 9 - metalizēts BOPET/PE (vide $-100 \% \mathrm{CO}_{2}$ ) ${ }_{2}$ absorbents, $100 \mathrm{~cm}^{3}$.

Fig. 2. The dynamics of moisture content in milk pomade sweets during storage time, $\%$ :

1 - Multibarrier 60 HFP pouches (control, air ambiance); 2 - Multibarrier 60 HFP pouches

(MAP 100\% $\mathrm{CO}_{2}$ ); 3 - Multibarrier $60 \mathrm{HFP}$ pouches (MAP 100\% $\mathrm{CO}_{2}$ ) $+\mathrm{O}_{2}$ scavenger, $100 \mathrm{~cm}^{3}$;

4 - Ceramis ${ }^{\circledR}-P L A$ pouches $\left(100 \% \mathrm{CO}_{2}\right) ; 5$ - Ceramis ${ }^{\circledR}-\mathrm{PLA}$ pouches $\left(100 \% \mathrm{CO}_{2}\right)+\mathrm{O}_{2}$ scavenger, $100 \mathrm{~cm}^{3}$;

6 - metallised NatureFlex 23NM (MAP 100\% $\mathrm{CO}_{2}$ ); 7 - metallised NatureFlex 23NM

(MAP 100\% $\mathrm{CO}_{2}$ ) $+\mathrm{O}_{2}$ scavenger, $100 \mathrm{~cm}^{3} ; 8$ - metallised BOPET/PE (MAP 100\% $\mathrm{CO}_{2}$ ); 9 - metallised BOPET/PE (MAP 100\% $\mathrm{CO}_{2}$ ) $+\mathrm{O}_{2}$ scavenger, $100 \mathrm{~cm}^{3}$.

paraugiem - gan ar absorbentu, gan bez tā - netika novērotas būtiskas atšksirības. Šerbeta cietība pēc 16 nedēḷu uzglabāšanas metalizētā NatureFlex $23 N M\left(100 \% \mathrm{CO}_{2}\right)$ materiālā bija $684.00 \pm 17.57 \mathrm{~N}$, bet metalizētā NatureFlex 23NM $\left(100 \% \quad \mathrm{CO}_{2}+\mathrm{O}_{2}\right.$ absorbents) - 604.34 $18.56 \mathrm{~N}$. Iepriekšminētie biodegradējamie materiāli ierobežo šerbeta uzglabāšanas laiku, tādēl produktu ilglaicīgai uzglabāšanai tie nav ieteicami - produkta cietība strauji palielinās un tā rezultātā netiek nodrošināta šerbeta kvalitāte.

Kontroles parauga cietība Multibarrier 60 HFP iepakojumā uzglabāšanas laikā pakāpeniski palielinājās līdz $356.26 \pm 8.53 \quad \mathrm{~N}$. Lietojot aizsarggāzu iepakošanas tehnologiju $\left(100 \% \quad \mathrm{CO}_{2}\right)$ un aktīvā iepakojuma tehnologiju $\left(100 \% \quad \mathrm{CO}_{2}+\mathrm{O}_{2} \quad\right.$ absorbents), cietība starp Multibarrier 60 HFP materiālā iepakotajiem paraugiem būtiski neatšksīrās un līdz uzglabāšanas 16. nedēḷai palielinājās attiecīgi līdz $295.83 \pm 8.21 \mathrm{~N}$ un $261.18 \pm 11.21 \mathrm{~N}$.

Būtiski mazākas cietības izmaiṇas novēroja, ja par iepakošanas materiālu bija izmantots metalizēts BOPET/PE. Aizsarggāzu vidē $\left(100 \% \quad \mathrm{CO}_{2}\right)$ iepakotā parauga cietība pēc 16 uzglabāšanas nedēḷām palielinājās tikai līdz $195.88 \pm 7.42$ N. Savukārt BOET/PE iepakojumā ar ievietotu $\mathrm{O}_{2}$ absorbentu šerbeta cietība pēc uzglabāšanas četrām nedẹ̦̄ām palielinājās līdz $186.92 \pm 8.63 \mathrm{~N}$; paraugu uzglabājot līdz 16 nedēḷām, neskatoties uz to, ka šerbeta mitrums turpināja nedaudz samazināties, produkta cietība nevis palielinājās, bet pakāpeniski samazinājās līdz $146.01 \pm 7.54 \mathrm{~N}$, t.i., par $21.5 \%$. Salīdzinot ar šerbeta sākuma cietību $55.80 \pm 2.96$ N, pēc 16 uzglabāšanas nedēl̦ām produkta cietība bija palielinājusies aptuveni trīs reizes, taču tas neatstāja būtisku ietekmi uz vērtētāju sajūtām, šerbetu sakožot. 
Lai izvērtētu šerbeta cietības izmaiņas uzglabāšanas laikā dažādos iepakojuma materiālos un dažādās vidēs, izmantojot 5 punktu hedonisko skalu, tika noteikta paraugu cietības robeža, kura rāda, kad produkts vēl ir pieņemams lietošanai. Salīdzinot sensoro vērtējumu rezultātus ar instrumentāli veiktajiem cietības mērījumiem, konstatējām, ka produktu var uzskatît par lietojamu (pieņemama cietības pakāpe) līdz cietības robežai $300 \mathrm{~N}$ (3. att.).

Vērtējumā iegūto datu analīze l̦auj secināt, ka, izmantojot dažādas iepakošanas tehnoloǵijas un dažādus iepakojuma materiālus, ieteicamais uzglabāšanas laiks piena pomādes konfektēm šerbetam - var būt atšķirīgs (2. tabula).

Nozīmīgs kvalitātes rādītājs ir krāsa, jo tā parasti ir pirmā pazīme, pēc kuras patērētājs novērtē produktu. Pētītajiem paraugiem krāsu noteica gan eksperimenta sākumā, gan visā uzglabāšanas laikā, kā arī aprēksināja krāsas parametru kopējo diferenci $\Delta \mathrm{E}^{*}$.

Šerbeta kopējā krāsas diference $\Delta \mathrm{E}^{*}$ uzglabāšanas laikā dažādos iepakojuma materiālos būtiski atšḳīrās $(\mathrm{p}<0.05) \quad$ (4. att.). Kontroles paraugam (gaisa vidē) Multibarrier 60 HFP iepakojumā (4. att. - 1) kopējā krāsas diference $\Delta \mathrm{E}^{*}$ uzglabāšanas laika beigās bija 4.96 vienības. Šajā materiālā aizsarggāzu vidē $\left(\begin{array}{lll}100 \% & \left.\mathrm{CO}_{2}\right)\end{array}\right.$ iepakotajam šerbetam kopējā krāsas diference $\Delta \mathrm{E}^{*}$ bija 6.45 vienības, bet iepakojumā ar skābekḷa absorbentu -7.31 .

Salīdzinot krāsu šerbeta paraugiem, kas iepakoti Multibarrier $60 \mathrm{HFP}$ (4. att. - 3) un metalizētā BOPET/PE (4. att. - 9) iepakojumā, redzams, ka 16 nedēḷu uzglabāšanas laikā aktīvajā iepakojumā (ar skābekḷa absorbentu) esošie paraugi bija

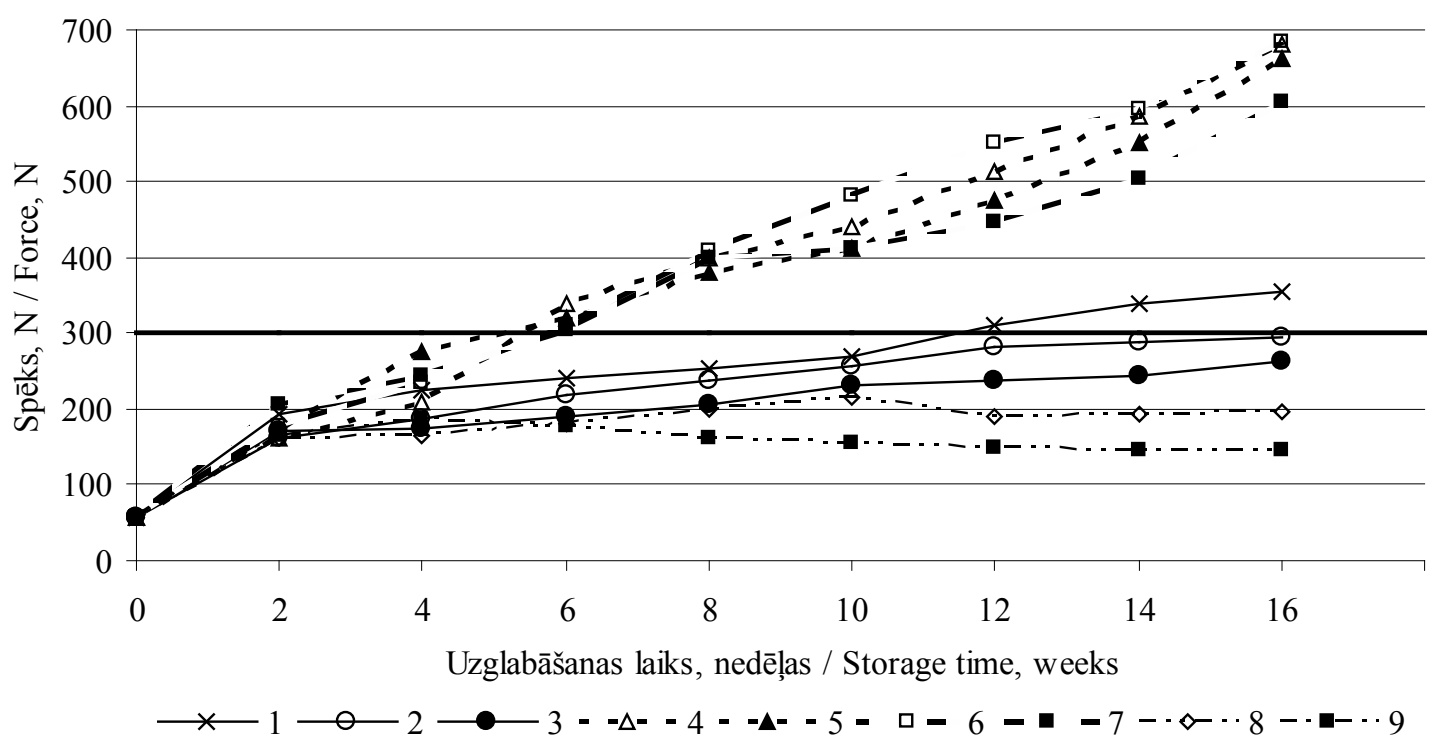

3. att. Šerbeta cietības (N) izmaiņas uzglabāšanas laikā:

1 - Multibarrier $60 \mathrm{HFP}$ (kontrole gaisa vidē); 2 - Multibarrier $60 \mathrm{HFP}\left(\right.$ vide $-100 \% \mathrm{CO}_{2}$ );

3 - Multibarrier $60 \mathrm{HFP}$ (vide - $100 \% \mathrm{CO}_{2}$ ) $+\mathrm{O}_{2}$ absorbents, $100 \mathrm{~cm}^{3} ; 4$ - Ceramis ${ }^{\circledR}$-PLA plēve

(vide $-100 \% \mathrm{CO}_{2}$ ); 5 - Ceramis ${ }^{\circledR}$-PLA plēve (vide $-100 \% \mathrm{CO}_{2}$ ) $+\mathrm{O}_{2}$ absorbents, $100 \mathrm{~cm}^{3}$;

6 - metalizēts NatureFlex 23NM (vide - 100\% $\mathrm{CO}_{2}$ ); 7 - metalizēts NatureFlex 23NM

(vide $\left.-100 \% \mathrm{CO}_{2}\right)+\mathrm{O}_{2}$ absorbents, $100 \mathrm{~cm}^{3} ; 8$ - metalizēts BOPET/PE (vide $-100 \% \mathrm{CO}_{2}$ ); 9 - metalizēts BOPET/PE (vide $\left.-100 \% \mathrm{CO}_{2}\right)+\mathrm{O}_{2}$ absorbents, $100 \mathrm{~cm}^{3}$, - - sensori noteiktā paraugu cietības robeža.

Fig. 3. The dynamics of texture $(\mathrm{N})$ changes in milk pomade sweets during storage time:

1 - Multibarrier 60 HFP pouches (control, air ambiance); 2 - Multibarrier 60 HFP pouches (MAP 100\% $\mathrm{CO}_{2}$ ); 3 - Multibarrier $60 \mathrm{HFP}$ pouches (MAP 100\% $\mathrm{CO}_{2}$ ) $+\mathrm{O}_{2}$ scavenger, $100 \mathrm{~cm}^{3}$;

4 - Ceramis ${ }^{\circledR}$-PLA pouches $\left(100 \% \mathrm{CO}_{2}\right) ; 5$ - Ceramis ${ }^{\circledR}$-PLA pouches $\left(100 \% \mathrm{CO}_{2}\right)+\mathrm{O}_{2}$ scavenger, $100 \mathrm{~cm}^{3}$;

6 - metallised NatureFlex 23NM (MAP 100\% $\mathrm{CO}_{2}$ ); 7 - metallised NatureFlex 23NM

(MAP $\left.100 \% \mathrm{CO}_{2}\right)+\mathrm{O}_{2}$ scavenger, $100 \mathrm{~cm}^{3} ; 8$ - metallised BOPET/PE (MAP $100 \% \mathrm{CO}_{2}$ ); 9 - metallised BOPET/PE (MAP $\left.100 \% \mathrm{CO}_{2}\right)+\mathrm{O}_{2}$ scavenger, $100 \mathrm{~cm}^{3}$, - - sensory estimated maximum hardness level. 


\section{E. Ungure et al. Novatoriska iepakojuma ietekme uz šerbeta kvalitāti uzglabāšanas laikā}

kḷuvuši tumšāki par aizsarggāzu vidē iepakotajiem paraugiem. Būtiskas $(p<0.05)$ krāsu izmaiņas varēja novērot paraugiem, kas iepakoti biodegradējamā
Ceramis ${ }^{\circledR}-P L A$ un metalizētā NatureFlex 23NM plēvē bez skābekḷa absorbenta - to krāsa bija kḷuvusi gaišāka (paraugs bālē).

2. tabula / Table 2

Ieteicamais uzglabāšanas laiks piena pomādes konfektēm - šerbetam

The recommended shelf life of milk pomade sweets - sherbet

\begin{tabular}{|c|c|c|c|}
\hline \multirow{4}{*}{$\begin{array}{l}\text { Paraugs / } \\
\text { Sample }\end{array}$} & \multicolumn{3}{|c|}{ Iepakošanas tehnoloǵija / Packaging technologies } \\
\hline & \multirow{2}{*}{$\begin{array}{l}\text { Gaisa vide / } \\
\text { Air ambiance }\end{array}$} & \multicolumn{2}{|c|}{ Aizsarggāzu vide / Modified atmosphere packaging } \\
\hline & & $100 \% \mathrm{CO}_{2}$ & $\begin{array}{c}100 \% \mathrm{CO}_{2}+\mathrm{O}_{2} \text { absorbents / } \\
100 \% \mathrm{CO}_{2}+\mathrm{O}_{2} \text { scavenger }\end{array}$ \\
\hline & \multicolumn{3}{|c|}{$\begin{array}{l}\text { Ieteicamais uzglabāšanas laiks, nedēlas/cietība } \\
\text { The recommended storage time, weeks/force }\end{array}$} \\
\hline $\begin{array}{c}\text { Multibarrier } 60 \text { HFP, } \\
\text { kontrole / control }\end{array}$ & $10-12 / 268-311 \mathrm{~N}$ & $16 / 295 \mathrm{~N}$ & $16 / 260 \mathrm{~N}$ \\
\hline Ceramis ${ }^{\circledR}-\mathrm{PLA}$ & - & $4-6 / 209-340 \mathrm{~N}$ & $4-6 / 274-320 \mathrm{~N}$ \\
\hline $\begin{array}{l}\text { Met. } \\
\text { NatureFlex 23NM }\end{array}$ & - & $6 / 310 \mathrm{~N}$ & $6 / 305 \mathrm{~N}$ \\
\hline Met. BOPET/PE & - & $16 / 195 \mathrm{~N}$ & $16 / 146 \mathrm{~N}$ \\
\hline
\end{tabular}

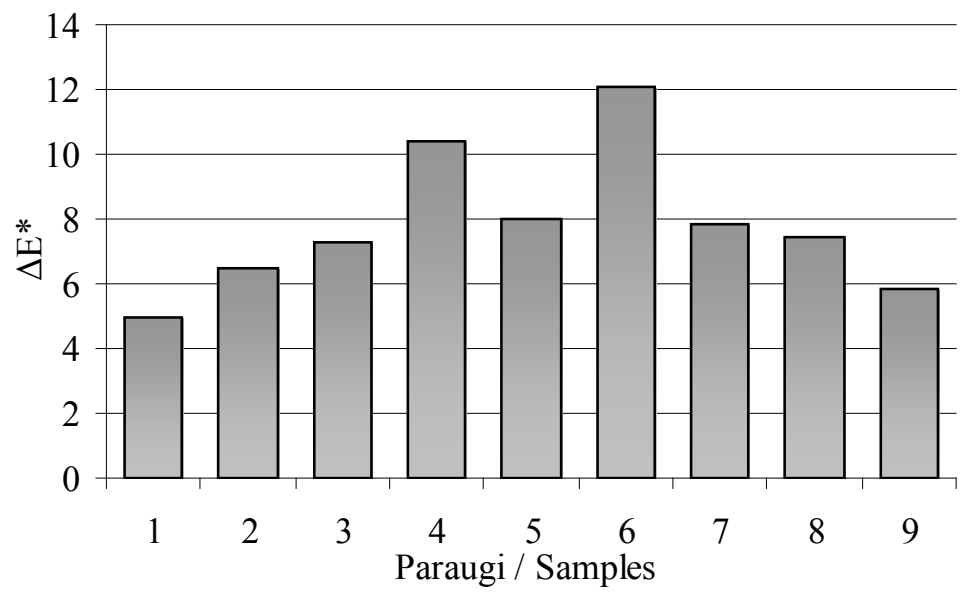

4. att. Iepakošanas tehnoloǵiju un materiālu ietekme uz šerbeta kopējo krāsas diferenci $\Delta \mathrm{E}^{*} 16$ uzglabāšanas nedēḷ laikā:

1 - Multibarrier 60 HFP (kontrole gaisa vidē); 2 - Multibarrier 60 HFP (vide - 100\% $\mathrm{CO}_{2}$ );

3 - Multibarrier $60 \mathrm{HFP}$ (vide - 100\% $\mathrm{CO}_{2}$ ) $+\mathrm{O}_{2}$ absorbents, $100 \mathrm{~cm}^{3} ; 4$ - Ceramis ${ }^{\circledR}$-PLA plēve

(vide - 100\% $\mathrm{CO}_{2}$ ); 5 - Ceramis ${ }^{\circledR}-P L A$ plēve (vide $\left.-100 \% \mathrm{CO}_{2}\right)+\mathrm{O}_{2}$ absorbents, $100 \mathrm{~cm}^{3}$;

6 - metalizēts NatureFlex 23NM (vide - 100\% $\mathrm{CO}_{2}$ ); 7 - metalizēts NatureFlex 23NM

(vide - 100\% $\mathrm{CO}_{2}$ ) $+\mathrm{O}_{2}$ absorbents, $100 \mathrm{~cm}^{3} ; 8$ - metalizēts BOPET/PE (vide $-100 \% \mathrm{CO}_{2}$ );

9 - metalizēts BOPET/PE (vide $-100 \% \mathrm{CO}_{2}$ ) $+\mathrm{O}_{2}$ absorbents, $100 \mathrm{~cm}^{3}$.

Fig. 4. The influence of packaging material on

the total colour difference $\Delta \mathrm{E}^{*}$ of sherbet samples during 16 storage weeks:

1 - Multibarrier 60 HFP pouches (control, air ambiance); 2 - Multibarrier 60 HFP pouches

(MAP 100\% $\mathrm{CO}_{2}$ ); 3 - Multibarrier $60 \mathrm{HFP}$ pouches (MAP 100\% $\mathrm{CO}_{2}$ ) $+\mathrm{O}_{2}$ scavenger, $100 \mathrm{~cm}^{3}$;

4 - Ceramis ${ }^{\circledR}-\mathrm{PLA}$ pouches $\left(100 \% \mathrm{CO}_{2}\right) ; 5$ - Ceramis ${ }^{\circledR}-\mathrm{PLA}$ pouches $\left(100 \% \mathrm{CO}_{2}\right)+\mathrm{O}_{2}$ scavenger, $100 \mathrm{~cm}^{3}$;

6 - metallised NatureFlex 23NM (MAP 100\% $\mathrm{CO}_{2}$ ); 7 - metallised NatureFlex 23NM

(MAP 100\% $\mathrm{CO}_{2}$ ) $+\mathrm{O}_{2}$ scavenger, $100 \mathrm{~cm}^{3} ; 8$ - metallised BOPET/PE (MAP 100\% $\mathrm{CO}_{2}$ );

9 - metallised BOPET/PE (MAP 100\% $\mathrm{CO}_{2}$ ) $+\mathrm{O}_{2}$ scavenger, $100 \mathrm{~cm}^{3}$. 


\section{Secinājumi}

Ilgstošai (līdz 16 nedēļām) šerbeta uzglabāšanai, nodrošinot nebūtiskas produkta kvalitātes izmaiñas, par labāko var rekomendēt metalizēto BOPET/PE iepakojuma materiālu.

Iepakošanas tehnoloǵiju salīdzinājums liecināja, ka piena pomādes konfekšu - šerbeta kvalitāti iespējams nodrošināt ilgāku uzglabāšanas laiku, ja iepakojuma materiālos - metalizētā BOPET/PE un Multibarrier 60 HFP - izmanto skābekḷa absorbentu. Savukārt dabai draudzīgajos iepakojuma materiālos - Ceramis $^{\circledR}-P L A$ plēvē un metalizētā NatureFlex 23NM ieteicamais šerbeta uzglabāšanas laiks bija līdz sešām nedẹ̦̄ām. Salīdzinot pêtījumā iekḷautos biodegradējamos materiālus, būtiskas atškirīības starp izmantotajām iepakošanas tehnoloǵijām netika novērotas.

\section{Literatūra}

1. Ahvenainen, R. (2003). An introduction: Active and intelligent packaging. In R. Ahvenainen (Ed.), Novel food packaging technologies (pp. 5-21). Cambridge, U.K: Woodhad Publishing.

2. Alkan packaging. (2006). Alkan Ceramis ${ }^{\circledR}-$ PLA, biodegradable barrier film. Retrieved from http://www.flexpack.org/MEMONL/mo sustainable_packaging/sp_member_initiatives/ Alcan/Alcan.pdf

3. Arella, M., Buzarovska, A., Errico, M.E., Gentile, G., \& Grozdanov, A. (2009). Ecochallenges of bio-based polymer composites. Journal of Materials, 2(3), 911-925.

4. Avella, M., De Vlieger, J.J., Errico, M.E., Fischer, S., Vacca, P., \& Volpe, M.G. (2005). Biodegradable starch/clay nanocomposite films for food packaging applications. Food Chemistry, 93(3), 467-474.

5. Barbiroli, G., \& Mazzaracchio, P. (1994). Classification and standardization of bakery products and flour confectionery in relation to quality and technological progress. Food Control, 5(1), 33-38.

6. Ben-Yoseph, E., \& Hartel, R.W. (2006). Computer simulation of sugar crystallization in confectionery products. Innovative Food Science and Emerging Technologies, 7(3), 225-232.

7. Bower, J.A. (2009). Statistical methods for food science: Introductory procedures for the food practitioner. Oxford, UK: Ames, Iowa: WileyBlackwell.

8. Ergun, R., Lietha, R., \& Hartel, R.W. (2010). Moisture and shelf life in sugar confections. Critical Reviews in Food Science and Nutrition, 50(2), 162-192.

9. Europe's packaging magazine Packaging today. (2007, September). Plastic fantastic. Retrieved from http://www.packagingtoday.co.uk/story. asp? storycode $=51652$

10. Farris, S., Schaich, K.M., Liu, L.S., Piergiovanni, L., \& Yam, K.L. (2009). Development of polyion-complex hydrogels as an alternative approach for the production of bio-based polymers for food packaging applications. Trends in Food Science and Technology, 20(8), 316-322.

11. Funabashi, M., Ninomiya, F., \& Kukioka, M. (2009). Biodegradability evaluation of polymer by ISO 14855-2. International Journal of Molecular Sciences, 10(8), 3635-3654.

12. Glaw, T. (2007, May). Transparent inorganic barrier properties. Retrieved from http:// www.tappi.org/content/events/07europlace/ presentation/07europl46.pdf

13. Innovia Films. (2006, July). First metallised Natureflex film launched. Retrieved from http:// www.ferret.com.au/c/Innovia-Films/Firstmetallised-natureflex-film-launched-n696221

14. Innovia Films. (2009, September). Sustainable, compostable NatureFlex ${ }^{\mathrm{TM}}$ film selected to package nutritional Canadian products. Retrieved from http://www.packaging-int.com/ article/sustainable-compostable-natureflexfilm-selected-to-package-nutritional-canadianproducts.html

15. Innovia Films. (2010, March). Metallised NatureFlex ${ }^{\mathrm{TM}}$ wraps Thorntons Melts. Retrieved from http://www.packaging-int.com/ article/metallised-natureflex-wraps-thorntonsmelts.html

16. Jensen, P.N., Sørensen, G., Brockhoff, P., \& Bertelsen G. (2003). Development of packaging systems for shelled walnuts based on oxygen absorbers. Journal of Agricultural and Food Chemistry, 51(17), 4941-4947.

17. Labuza, T., Roe, K., Payne, C., Panda, F., Labuza, T.J., Labuza, P.S., \& Krusch, L. (2004). Storage stability of food systems: Influence of state changes during drying and storage. In Proceedings of the 14th International Drying 
Symposium (IDS 2004), 22-25 August 2004 (pp. 48-68). Säo Paulo, Brazil.

18. Lagaron, J.M., \& López-Rubio, A. (2010). Latest developments and future trends in food packaging and biopackaging. In M.L. Passos \& C.P. Ribeiro (Eds.), Innovation in food engineering new techniques and products (pp. 485-503). USA: CRC Press Taylor \& Francis Group.

19. López-Carballo, C., Catalá, R., Gavara, D., \& Hernįndez-Muńoz, P. (2011). Food applications of active packaging EVOH films containing cyclodextrins for the preferential scavenging of undesirable compounds. Journal of Food Engineering, 104(3), 380-386.

20. Lopez-Rubio, A., Almenar, E., HernandezMunoz, P., Lagaron, J.M., Catala, R., \& Gavara, R. (2004). Overview of active polymer-based packaging technologies for food applications. Food Reviews International, 20(4), 357-387.

21. MacDougall, D.B. (2002). Colour measurement of food: Principles and practice. In D.B. MacDougall (Ed.), Colour in food. Improving quality (pp. 33-63). Cambridge, England: Woodhead Publishing Ltd.

22. Manley, D. (1998). Biscuit, cookie and cracker manufacturing: Manual 1 - Ingredients. Cambridge, UK: Woodhad Publishing Limited.

23. Mathlouthi, M. (Ed.). (1994). Food packaging and preservation. London: Blackie Academic and Professional.

24. Meyer, A.R. (2007). Bio-packages to raise organic food's estimation. PLA bio-plastics trays for high-quality fresh foods and convenient foods under MAP. Fleischwirtschaft International, 5, 45-48.

25. Mexis, S.F., Badeka, A.V., Riganakos, K.A., \& Kontominas, M.G. (2010). Effect of active and modified atmosphere packaging on quality retention of dark chocolate with hazelnuts. Innovative Food Science and Emerging Technologies, 11(1), 177-186.

26. Mitrus, M., Wojtowicz, A., \& Moscicki, L. (2009). Biodegradable polymers and their practical utility. In L. Janssen \& L. Moscicki (Eds.), Thermoplastic starch (pp. 1-33). Weinheim: WILEY-VCH Verlag GmbH \& Co. KGaA.

27. Narayan, R. (2001). Drivers for biodegradble/ compostable plastics and role of composting in waste management and sustainable agriculture. Report Paper. Orbit Journal, $1(1), 1-9$.

28. NatureFlex. (2010, April). Cadbury Flake uses NatureFlex ${ }^{\mathrm{TM}}$. Retrieved from http://www. innoviafilms.com/NatureFlex/News/MediaCentre. $\operatorname{aspx}$ ?id=7

29. Pastorelli, S., Torri, L., Rodriguez, A., Valzacchi, S., Limbo S., \& Simoneau, C. (2007). Solid-phase micro-extraction (SPME-GC) and sensors as rapid methods for monitoring lipid oxidation in nuts. Food Additives and Contaminants, 24(11), 1219-1225.

30. Quinton, L.A., \& Kennedy, J.F. (2002). Book review: The science of sugar confectionery W.P. Edwards, The Royal Society of Chemistry, 2000. Carbohydrate Polymers, 47(1), 88-89.

31. Raisi, A., \& Aroujalian, A. (2007). Reduction of the glucose syrup browning rate by the use of modified atmosphere packaging. Journal of Food Engineering, 80(1), 370-373.

32. Reinheimer, M.A., Mussati, S., \& Scenna, N.J. (2010). Influence of product composition and operating conditions on the unsteady behavior of hard candy cooling process. Journal of Food Engineering, 101(4), 409-416.

33. Reinheimer, M.A., Mussati, S., Scenna, N.J., \& Pérez, G.A. (2010). Influence of the microstructure and composition on the thermal-physical properties of hard candy and cooling process. Journal of Molecular Structure, 980(1-3), 250-256.

34. Restuccia, D., Spizzirri, U.G., Parisi, O.I., Cirillo, G., Curcio, M., Iemma, F., ... Picci, N. (2010). New EU regulation aspects and global market of active and intelligent packaging for food industry applications. Food Control, 21(11), 1425-1435.

35. Rooney, M.L. (1995). Active food packaging. London, UK: Chapman \& Hall.

36. Rooney, M.L. (2005a). Introduction to active food packaging technologies. In J.H. Han (Ed.), Innovations in food packaging (pp. 63-80). Oxford, UK: Elsevier Academic Press.

37. Rooney, M.L. (2005b). Oxygen-scavenging packaging. In J.H. Han (Ed.), Innovations in food packaging (pp. 123-138). Oxford, UK: Elsevier Academic Press.

38. Scussel, V.M., Tanello, A.C., Giordano, B.N., Manfio, D., Galvão, S., \& Rodrigues, M.N.F. (2010). Effect of oxygen reducing atmospheres on the quality and safety of stored shelled Brazil nut packs. In Proceedings of the 
10th International Working Conference on Stored Product Protection, 27 June-2 July 2010 (pp. 560-565). Estoril, Portugal.

39. Silagyi, K., Kimn, S.H., Lo, Y.M., \& Wei, C. (2009). Production of biofilm and quorum seeming by Escherichia coli 0 157:H7 and its transfer from contact surfaces to meat, poultry, ready-to-eat deli, and produce products. Journal of Food Microbiology, 6(26), 514-519.

40. Siracusa, V., Rocculi, P., Romani, S., \& Rosa, D. (2008). Biodegradable polymers for food packaging. Trends in Food Science \& Technology, 19(12), 634-643.

41. Sucharzewska, D., Stochmal, A., \& Oleszek, W. (2003). The effect of Yucca schidigera extract on the physical structure and on the oxidative stability of sugar-candy foam products. Lebensmittel Wissenschaft und Technologie, 36(3), 347-351.

42. Talja, R.A., Helen, H., Roos, Y.H., \& Jouppila, K. (2008). Effect of type and content of binary polyol mixtures on physical and mechanical properties of starch-based edible films. Carbohydrate Polymers, 71(2), 269-276.

43. Taub, I.A., \& Singh, R.P. (Eds.) (1998). Food storage stability. CRC Press.

44. Tharanathan, R.N. (2003). Biodegradable films and composite coatings: Past, present, and future. Trends in Food Science and Technology, 14(3), 71-78.

45. Thippeswamy, L., Venkateshaiah, B.V., \& Patil, S.B. (2011). Effect of modified atmospheric packaging on the shelf stability of paneer prepared by adopting hurdle technology. Journal of Food Science and Technology, 48(2), 230-235.

46. Vaclavik, V.A., \& Christian, E.W. (2008). Sugar sweeteners, and confections. Essentials of Food Science (3rd ed.) (pp. 331-348). New York: Springer Science+Business Media, LLC.

47. Veiga-Santos, P., Suzuki, C.K., Nery, K.F., Cereda, M.P., \& Scamparini, A.R.P. (2008). Evaluation of optical microscopy efficacy in evaluating cassava starch biofilms microstructure. LWT - Food Science and Technolog, 41(8), 1506-1513.

48. Vermeiren, L., Devleighere, F., van Beest, M., de Kruijf, N., \& Debevere, J. (1999). Developments in the active packaging of foods. Trends in Food Science and Technology, 10(3), 77-86.

49. Vorman, I., \& Tighzert, L. (2009). Biodegradable polymers. Journal of Materials, 2(2), 307-344.

50. Zumbé, A., Lee, A., \& Storey, D. (2001). Polyols in confectionery: The route to sugar-free, reduced sugar and reduced calorie confectionery. British Journal of Nutrition, 85, 31-45.

\section{Pateicība}

Pētījums veikts ar Eiropas Savienības Sociālā fonda (ESF) projekta atbalstu „,Atbalsts doktora studijām LLU”, līguma Nr. 2009/0180/1DP/1.1.2.1.2./09/IPIA/VIAA/017. 